\title{
Vaginal Birth Mechanism
}

National Cancer Institute

\section{Source}

National Cancer Institute. Vaginal Birth Mechanism. NCI Thesaurus. Code C92912.

The natural processes involved in giving birth vaginally. 